\title{
How is the business case used by stakeholders for making project decisions with PFI/PPP projects?
}

\author{
M. J. Gannon \\ Westminster Business School, University of Westminster, London, UK
}

\begin{abstract}
In the United Kingdom (UK) Metro and Light Rail projects (new schemes, extensions and enhancements) are traditionally promoted by public sector sponsors within an extensive network of public and private sector stakeholders. This structure of public and private stakeholders has emerged since the structural and funding changes to the UK rail industry that occurred in the early 1990s; particularly the case with Public-Private-Partnership/Private Finance Initiative (PPP/PFI) rail projects. This complex stakeholder network includes: private sector infrastructure providers, train-operating companies; and public sector County Councils, Government departments and advisors and consultants from the private sector acting on their behalf.

Each group of project sponsors needs to address a range of complex project decisions throughout the project's development period. The business case provides decision makers with a tool to analyse and assess options to inform and justify the impact of these project decisions. Therefore the information contained within the business case is critical to facilitate successful project decision-making. Although literature provides a best practice for the business case form and an outline of expected project decisions, it provides minimal information regarding the nature of these decisions and how the business case and supporting information is used in addressing these decisions.
\end{abstract}

Keywords: PFI/PPP projects, business case, decision making, rail projects. 


\section{Introduction}

Rail schemes in the United Kingdom (UK) often take longer to progress through the development cycle than project sponsors and the general public expected. Many schemes appear to remain on the "drawing board" in some cases for nearly a decade. Two fine examples of this are Croxley Rail Link [1] and Crossrail [2].

During the development stage, projects waiting for a "green light" to commence the planning process for a Transport and Works Act order (TWA) undergo a business case scrutiny check firstly by corporate decisions makers and then Government decision makers. During this second scrutiny by Transport authorities, projects undergo a barrage of business case related questions and enter into a seemingly perpetual cycle of questions and requests for project information from project sponsors and their advisors by the policy and decisions makers. The reason for this state of perpetual "development suspension" has two aspects. From the critics perspective it is due to the indecision of the policy and decision makers who sometimes appear to ask continual questions regarding the business case with perhaps a hope of delaying the approval decision; and from the policy and decision makers perspective it is due to the sponsor not providing sufficient information or in the form requested or modelling inconsistencies have been found and need resolving. Either way the project is on hold and becomes delayed in its fight for approval. In extreme cases structural changes have occurred to the industry during this time.

Similarly during the transaction stage projects can also be subject to major delays often bordering on having the project halted: due to political disagreement as was the case with London Underground's Public-Private-Partnership (PPP); or project's bid costs exceeding the Government's expectations as was the case with three Light Rail Transit (LRT) UK schemes [3]: Leeds SuperTram (41\% higher than expected), Manchester Metro (73\% higher than expected) and South Hampshire Rapid Transit (59\% higher than expected).

This prolonged wait for rail investment in the UK is sometimes not helped by the seemingly lack of decision making and unsuccessful decision making that occurs based on the information contained in a scheme's business case [3]. Additionally when a decision is made, "go or no-go", by the policy and decision makers, there is often limited transparency provided to project sponsors or the general public regarding how the decision was made. This is not helped when critical information on which the project decision was made is excluded from the business case framework.

The aim of the paper is to investigate using a qualitative Case Study and Survey research method how the business case and supporting information is used by public sector project stakeholders (decision makers) to support project decision making for PFI/PPP projects during the development phase. The investigation will focus on identifying key project decisions, the business case form and additional information used in the decision making process; and contrast these findings with the best practice business case form appropriate for decision making advocated in literature to identify any shortcomings with the business case that could be used to facilitate improved decision making with projects. 


\section{Public Finance Initiative/ Public-Private-Partnerships (PFI/PPP)}

\subsection{What is PFI/PPP?}

According to Li et al [4] there are eight models of Public-Private-Partnerships (PPP's) of which PFI is the most commonly used form in the UK. PFI is essentially where the public sector contracts with a private sector consortium on a long-term basis often between 20 to 30 years to deliver services. During this period the private sector typically Designs, Builds, Finances, Operates and Maintains (DBFOM) the assets and provides a service to the client according to a performance specification. There is a close proximity between the PFI model and the PPP model as used to fund London's Underground system [5]; PPP in this case was used generically however was best described as an acquisition and a variation of the PFI model incorporating lessons learnt from the UK Rail privatisation.

The initiative has offered a means of funding large-scale public sector projects whilst not impacting on the Government's public sector borrowing requirement (PSBR) and has allowed private sector skills and innovations to be brought into the public sector to improve efficiency and provide Value for money (VfM). For contractors the initiative provides a 'golden opportunity' to secure long-term contracts with a steady payment stream in return for a delivered service.

\subsection{Extent of PFI/PPP projects in the United Kingdom}

Public-Private-Partnerships (PPP) bring together the public and private sectors in a long-term partnership. It has been an innovative means by which the public sector has attracted the private sector to invest in public services. The years 1987 to 2004 has witnessed nearly $£ 40$ billion of private capital invested in 626 projects across 20 public sectors departments, see Figure 1. Although prior to 1992 private investment in public sector projects was governed by the Ryrie Rules. The most significant of this expenditure and most complex projects have been within the transport sector where nearly $50 \%$ of this expenditure has occurred. With the Health sector witnessing the largest number of PFI projects signed in the UK.

At present PFI/PPP represents an extremely important method to Her Majesty's Treasury (HMT) of financing public sector projects. PFI has provided a means of reaching those parts of the public sector where privatisation was not possible whether this was due to social policy, lack of financial viability or where the full cost of the industry could not be met from the users or all of these [6]. Such examples where this initiative has been applied to investment in public services include: roads, hospitals, schools, prisons, defence, light rail and metro systems see Figure 1. 


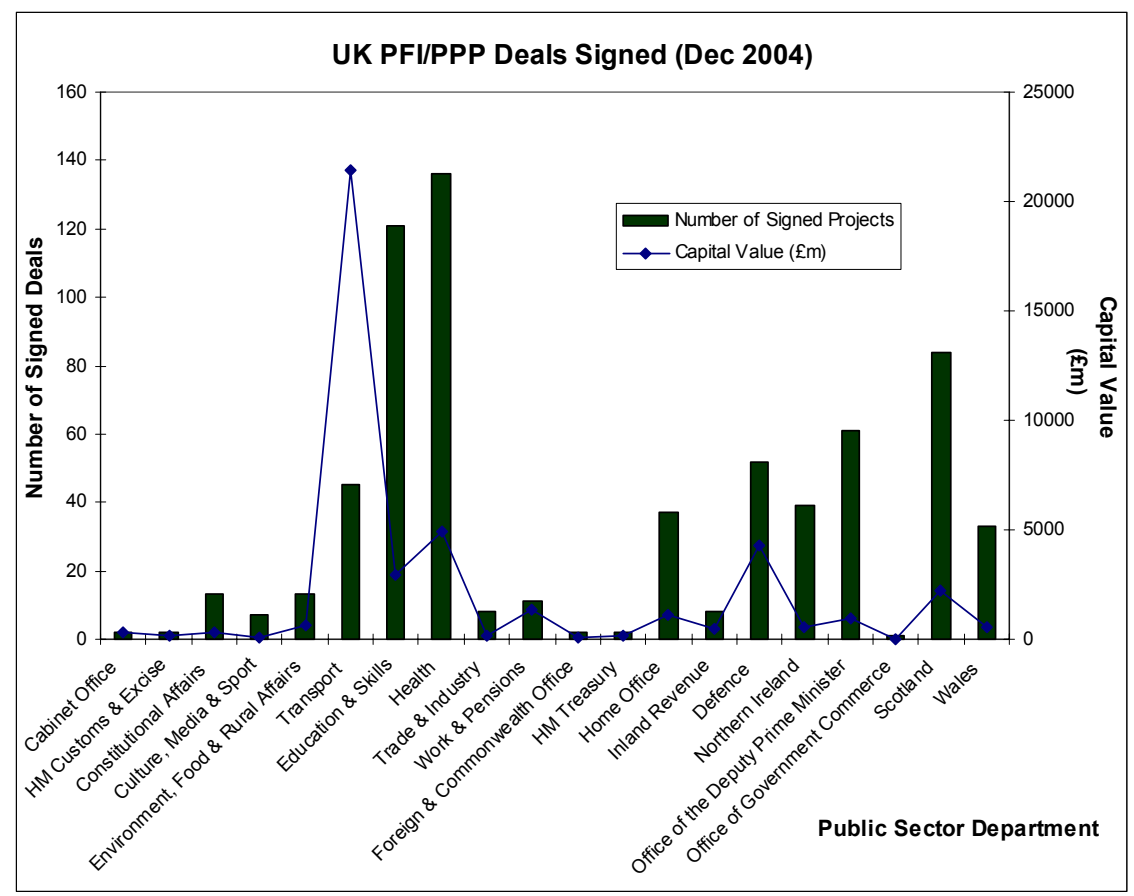

Figure 1: $\quad$ Number of PFI/PPP deals signed by public sector department in the UK Between 1987-2004 [7].

\subsection{Project stakeholders in PFI/PPP projects}

Project stakeholders refer to those groups who are positively or negatively affected by the delivery of the project [8]. Figure 2 illustrates the groups of project stakeholders for a rail project positioned against their project decision making authority with the business case and business case information available to the stakeholder on which to base their decision. Project sponsors and corporate sponsors are those groups on a project who have authority for decision making with the business case. Project sponsors usually make decisions during the development of the business case and corporate sponsors make strategic project decisions using the business case.

The project sponsors supported by their advisors are the best informed with business case information in terms of the development of the case and why decisions were taken at the project level. Whereas at the corporate level this "development" information is summarised and included within the business case for decision making purposes although not all of this information will be known on which the decision is made. 


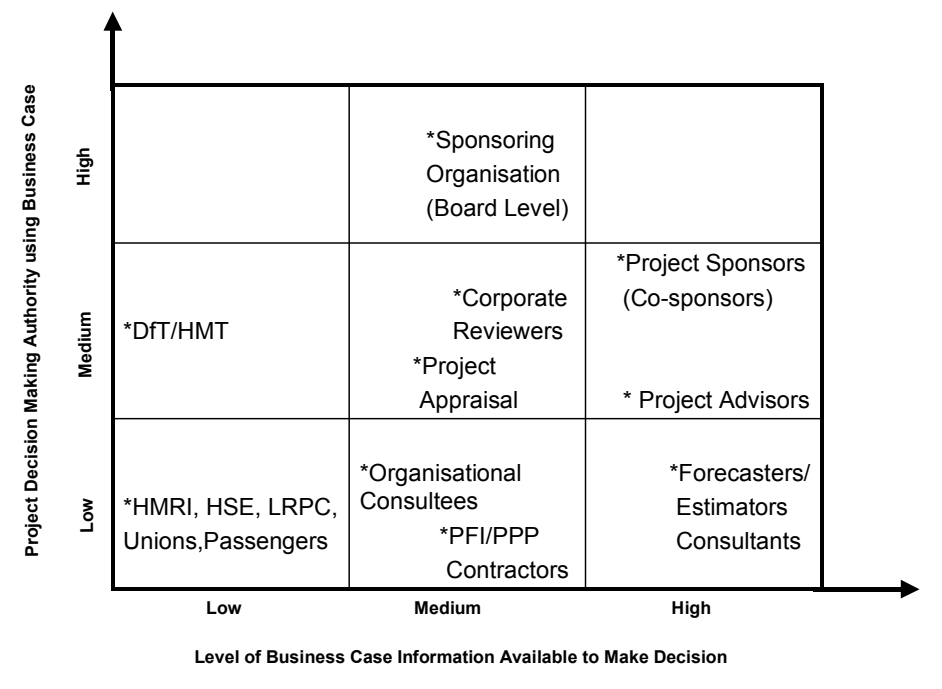

Figure 2: $\quad$ Stakeholders used in project decision making and availability of information on which to base decision.

\section{The business case}

\subsection{Purpose}

The purpose of the business case is well established by decision makers. A business case is used as a means of obtaining management commitment and approval for an investment providing business change through a clearly presented rational; and a framework (structure and contents) for informed decision making in planning and management of the business change and subsequent benefit realisation [9]. According to references [10] and [11] the purpose of the business case is to provide all the information needed to make an informed decision as to whether a project should be funded. However the business case in many organisations is limited to the quantitative aspects of the project rather than the wider project aspects on which the project decision is based.

\subsection{A best practice framework}

The OGC $[9,11]$ have suggested a general framework for the business case that comprises of five cases: linking the organisation and its corporate strategy to the project's economics and finance and the organisation's ability to deliver the project, see Table 1. The five cases include $[12,13]$ : The Strategic Case (Strategic fit), The Economic Case (Options appraisal), The Value for Money Case (Commercial aspects), The Financial Case (Affordability) and The Project 
Management Case (Achievability). The Strategic case is equivalent to the Project Brief in PRINCE2 ${ }^{\mathrm{TM}}$ and is often identified prior to the development of the project; the Economic Case and Project Management Case are part of the Project Information Document (PID) in PRINCE2 ${ }^{\mathrm{TM}}$.

Each of the five cases has elements that are essential to capture project information on which to make investment decisions [13]. Information relating to the corporate, finance and planning, aspects of a project is covered by Strategic Fit and Affordability. Information relating to the project itself is covered within the Options Appraisal, Commercial and Achievability. Commercial aspects are considered in the project's business case when the project is procured using PFI/PPP. Each of these cases seeks to establish whether the project: will meet the need of the business (Strategic Fit); progress the most appropriate option (Options appraisal); demonstrate the preferred option is fully achievable (Achievability) and the organisation fully understands the project implications; is affordable over the project's whole life especially including service changes (Affordability); and has sound commercial arrangements for external procurement and demonstrates value for money (Commercial). This framework can be used as a business case for all types and sizes of projects.

\section{Research methodology}

A qualitative case study and survey research strategy utilising PFI/PPP metro and light rail projects was used to investigate: project decisions made; information that was used to support these decisions; and information boundaries of the business case. The case studies were selected due their position within the project development stage and also due to their differences in nature. For instance underground, surface line projects and light rail.

Data collection was by way of semi-structured interviews, transcribed, with project stakeholders; corporate finance, project sponsors and consultants who were responsible for developing cost and revenue forecasts for these projects to provide a context to the three areas under investigation. Project reports were reviewed to business case related information used in decision-making. This provided material from which key information themes were identified and analysed using within case analysis. The affordability decision was the main project decision investigated with each of the case studies.

\section{PFI/PPP project decision making and information used}

\subsection{Project decision and business case form}

The form of the business case specified in each of the cases investigated was dependent upon whether the investment, procurement or financing project decision was being addressed. Table 1 shows the 'Project Decision', the 'Business Case' form and the 'Purpose' of the business case [14]. With PFI/PPP projects the procurement and financing decision are the same decision. Figure 3 show the business case equations used to calculate each business case.

Each of the three business cases, shown in Table 1, use common cost and revenue components, with the exception of the economic case that uses social 
benefits. In either case components are combined and it is their purpose that really distinguishes the form of each business case.

Table 1: $\quad$ Business cases required for PFI/PPP projects.

\begin{tabular}{|l|l|l|}
\hline \multicolumn{1}{|c|}{ Project Decision } & \multicolumn{1}{c|}{ Business Case } & \multicolumn{1}{c|}{ Purpose } \\
\hline $\begin{array}{l}\text { Is the investment } \\
\text { Justified? }\end{array}$ & $\begin{array}{l}\text { Economic case: } \\
\text { Options Appraisal }\end{array}$ & $\begin{array}{l}\text { To assess whether the } \\
\text { Investment is } \\
\text { worthwhile. }\end{array}$ \\
\hline $\begin{array}{l}\text { Does the investment } \\
\text { provide value for } \\
\text { money to the public } \\
\text { sector implementing } \\
\text { the project using } \\
\text { PFI/PPP? }\end{array}$ & $\begin{array}{l}\text { Value for Money } \\
\text { (VfM): }\end{array}$ & $\begin{array}{l}\text { To assess whether the } \\
\text { project should be funded } \\
\text { and procured by using } \\
\text { PFI/PPP or traditionally } \\
\text { (i.e. grant). }\end{array}$ \\
\hline $\begin{array}{l}\text { Is the project delivered } \\
\text { using PFI/PPP } \\
\text { affordability to the } \\
\text { public sector? }\end{array}$ & $\begin{array}{l}\text { Financial Case: } \\
\text { Affordability }\end{array}$ & \\
\hline
\end{tabular}

(i) Economic Case: The economic case provided comfort for the economic justification of the project. This is required before proceeding with the PFI/PPP procurement route. It determines the benefit to society of carrying out the project. A key point with this analysis was that only incremental costs, revenues and benefits associated with the investment were considered. A benefit to cost ratio (BCR) was determined and used to assess whether the projects were a worthwhile investment.

(ii) Value for Money Case: Two business cases are prepared to determine Value for Money (VfM), the Private Finance Initiative (PFI) case and the Public Sector Comparator (PSC). Each of these cases were prepared to assess and compare the cost to the public sector, on a whole life basis, of undertaking the project under PFI/PPP or through traditional means using a 'hypothetical' comparator namely the PSC.

At the development stage the PFI business case was governed by the project's intended contractual model. This was comprised of the project's revenue, service charge costs (for a given level of service) and risks retained by the public sector. The service charge represents the private sectors revenue stream from the project. This was calculated by deriving the rate of return for the project from the project's cash flows; where the cash flows covered the private sector's capital and operating costs and risks for undertaking the projects. The PSC was a theoretical business case to determine the cost of carrying out the project using traditional procurement. This case assumed grant was not constrained and reflected the cost and the total risk to the public sector of implementing the project's performance specification.

(iii) Financial Case: This was used to assess the affordability of the project to the public sector and was an analysis of the case for incremental project revenue less incremental service charge incurred for the PFI/PPP project. The emphasis 
was on determining the impact of the project on the gross margin and whether the project was affordable to sponsors. A project might well represent VfM however is unaffordable to the organisation. The project's cashflow statement was used to inform and justify the Net Financial Effect to the sponsoring organizations.

Economic Justification:

$\mathrm{BCR}=\mathrm{NPV}[$ Social Benefits $] / \mathrm{NPV}[\mathrm{NFE}]$

If BCR> Threshold investment justified.

Value for Money Decision:

VFM $=$ NPV $[$ PSC Costs + Risk $]-$ NPV [PFI Service Charges + Risk $]$

If $\mathrm{VFM}>0$ Value for money has been achieved.

Affordability Decision:

NFE $=$ NPV[Revenues]-NPV[PFI Service Charges $]$

Figure 3: $\quad$ PFI/PPP business case equations.

\subsection{Information used in decision making}

Although not considered as part of the business case by the sponsors wider project information was also considered as part of the affordability decision making process. A sample of this information used to support this decision making is shown in Table 2. With the cases examined the business case was often synonymous with an appraisal and hard information (quantitative) rather than soft information (qualitative). The business case information was represented at two levels the Corporate decision making level and the Project level; containing the financial model and the detailed development knowledge of the project and business case.

\section{Shortcomings of the business case}

The project sponsor's business case predominantly contained hard financial information therefore not surprisingly its role was restricted to the financial analysis that played a minimal role in project decision making. It was evident significant soft information was utilised in the project decision making process outside the sponsor's business case, see Table 2. This exclusion of information from the business case removed transparency in the decision making process.

Equally the business case used for decision making at the corporate level provided no indication to decision makers of the development process. For instance nothing is brought to the corporate decision makers attention in a 
business case framework regarding model calibration or validation, forecasting methodology, capability and experience of forecasters or data sources. These elements are often researched by the project sponsor before making a corporate decision but not included within the business case framework to facilitate good practice.

Table 2: Hard and soft information used by sponsors in project decision making.

\begin{tabular}{|l|l|}
\hline \multirow{4}{*}{$\begin{array}{c}\text { Hard } \\
\text { Information }\end{array}$} & $\begin{array}{l}\text { Information Used in Project Decision Making } \\
\text { case. }\end{array}$ \\
\cline { 2 - 3 } & Cashflow with scenarios \\
\cline { 2 - 3 } & Cashflow with sensitivities \\
\cline { 2 - 3 } & Benchmarking outturn capital and operating costs with project costs. \\
\cline { 2 - 3 } Soft & Benchmarking operating costs and revenues with operating system. \\
\cline { 2 - 3 } & Benchmark revenue forecasts against revenue forecasts form other models. \\
\cline { 2 - 3 } & Quantitative risk register \\
\hline & Sponsor's statutory obligations \\
\cline { 2 - 3 } & Sponsors's existing project commitments and priorities \\
\cline { 2 - 3 } & Co-sponsors business need and urgency \\
\cline { 2 - 3 } & Co-sponsors financial return \\
\cline { 2 - 3 } & Co-sponsors relationship with consultants and information control \\
\cline { 2 - 3 } & Government Authorities project expectation and position \\
\cline { 2 - 3 } & Political support for project (MP's, Mayor) \\
\cline { 2 - 3 } & Opinions of senior stakeholders \\
\cline { 2 - 3 } & Sponsor's long term policies (fares and operations) \\
\cline { 2 - 3 } & Five year budgeted amount for project \\
\cline { 2 - 3 } & Existing board papers and agreed status of project \\
\cline { 2 - 3 } & Lessons learnt on previous projects \\
\cline { 2 - 3 } & Judgement of bias of information \\
\cline { 2 - 3 } & Discussions/ agreements made at Senior Management level \\
\hline & Contractual model precedents \\
\cline { 2 - 3 } & Contractual principles (proposed or existing) \\
\cline { 2 - 3 } & Qualitative risk register \\
\hline
\end{tabular}

Having investigated the case studies there is an argument to widen the boundaries of the business case to include this information within the case to provide transparency with decision-making. Additionally there is an argument to deepen the business case to capture critical business case development information from the project team for corporate level decision makers thus providing a framework to facilitate improved decision making.

\section{Conclusion}

Best practice business case frameworks provide a useful template for the business case however there are information shortcomings in terms of its width and depth. Investigating the case studies has demonstrated the business case is often associated with an appraisal and its role limited to quantitative aspects supported by wider project information used in decision-making. However this wider information used for decision-making is not cited as part of the business case framework although is critical information. 
To provide transparency in decision making it is essential all information used in the process is included within the business case framework. By providing an additional detailed framework in which to capture business case development information will provide decision makers with further assurance decisions are made on a credible business case. Supplementing this form of business case with lessons learnt from past projects will provide a business case framework that would facilitate improved decision making with projects thereby reducing wasted costs and time. The development of a new business case framework to facilitate improved project decision-making is currently being researched at the University of Leeds by the author.

The contents of this paper represent the views of the author and do not represent University of Westminster's policy. The author does not accept any liability for its correctness

\section{References}

[1] Beherman, D. (2004). Rail link moves a step closer to being realised. Watford Observer. Watford: $\mathrm{p} 3$.

[2] Murray, D. and R. Lydall (2004). After 15 years no Crossrail - but an astonishing $£ 30 \mathrm{~m}-\mathrm{a}-\mathrm{year}$ bill. Evening Standard. London: p8-9.

[3] HC (2005) House of Commons, Transport Committee Integrated Transport: The Future of Light Rail and Modern Trams in the United Kingdom, HC 378-1, 3 April 2005.

[4] Li Bing, A. Akingtoye, P.J. Edwards and C Hardcastle (2005), Critical Success Factors for PFI/PPP Projects in the UK Construction Industry, Construction Management and Economics (June 2005), 23, p459-471.

[5] Gannon (2002). Funding London's Underground Using PPP? European Transport Conference, Homerton College, Cambridge University.

[6] Morton, A. S. (1998). "The Developing Initiative." Private Finance initiative Journal 3(2): p6-7.

[7] HMT (2004). PFI/PPP Signed deals up to 2004.

[8] Gardiner Paul. D Project Management: A Strategic Planning Approach, Pelgrave Macmillian, 2005.

[9] OGC (2002) Office for Government and Commerce, Successful Delivery Toolkit, www.ogc.gov.uk/sdtoolkit/bclifecycle/b/b2.html.

[10] Schmidt, M.J 1999 What's a Business Case? And Other Frequently Asked Questions. Solution Matrix, Ltd: www.solutionmatrix.com.

[11] Marchewka, J.T Information Technology Project Management, Second Edition, John Wiley and Sons, 2006.

[12] OGC (2003) Office for Government and Commerce, Business Case Template, www.ogc.gov.uk/sdtoolkit/reference/documentation/p13buscase.html (March).

[13] OGC (2004) Office for Government and Commerce, Business Case Development Overview, www.ogc.gov.uk/sdtkdev/examples/dwp life/ prodsets/strands/fbc hgc.doc.

[14] Gannon (2004) A Review of Techniques Used to Assess the Credibility of a Business Case in Public Sector Rail Projects, COMPRAIL2004, Dresden. 